\title{
Scientific Management Strategy of Scientific Research Funds in Local Colleges and Universities
}

\author{
Dahua Wang \\ Jilin Engineering Normal University, Changchun, Jilin \\ 894161521@qq.com
}

\begin{abstract}
Keywords: Local colleges and universities; Scientific research in colleges and universities; Scientific research funds; Scientificalness; Management
\end{abstract}

\begin{abstract}
The fund of scientific research in colleges and universities is the basis for the smooth development of the scientific research work in colleges and universities. Only by constantly strengthening their financial management and improving the scientificalness of the use of scientific research funds, can universities ensure that the funds of scientific research play the most important role. From a macro perspective, the management of scientific research funds in China's colleges and universities has been developing in a positive direction. However, from the perspective of details, there are always some problems in the management process of scientific research funds in local colleges and universities. This will not only affect the development of scientific research level in colleges and universities, but also waste valuable scientific research funds and influence the development of scientific research in colleges and universities. Actively designing strategies to optimize the management of scientific research funds in local colleges and universities is an "urgent task" at the present stage, and the relevant personnel of local colleges and universities need to pay attention to it.
\end{abstract}

\section{Introduction}

Like ordinary universities, scientific research is a key point in the work of local colleges and universities. However, due to the lack of thinking and understanding, the management work of scientific research funds of many local colleges and universities relatively lags behind, and there are many problems in the management process, so the normal development of scientific research activities in colleges and universities is also impeded frequently. In order to ensure the rational use of scientific research funds, and further improve the level of scientific research work in local colleges and universities, universities need to further study the management of scientific research funds and improve the overall level of scientific research funds management.

\section{The Problems Existing in the Management of Scientific Research Funds in Local Colleges and Universities}

There is no doubt that the local colleges and universities have problems in the management of scientific research funds, but from a whole point of view, there are some problems such as incorrect management attitude, imperfect management system and nonstandard management behavior. Now, we will discuss these problems in detail.

Incorrect Management Attitude. In the process of applying scientific research funds, the scientific research organizations and researchers in local colleges and universities often need to spend a lot of time and energy. Because of this, many local colleges and universities believe that scientific research funds are applied by scientific research organizations and researchers, and the ownership of scientific research funds belongs to all scientific research organizations, so local colleges and universities do not interfere or rarely interfere with them. Because of the above wrong thought, the management of scientific research funds in local colleges and universities is often more casual. In order to improve the achievements of scientific research, many scientific research personnel completely ignore the scientific research funds. At the same time, although scientific research funds rely on the financial appropriations, the management of scientific research funds in 
many local colleges and universities does not strictly follow the fund management system of financial appropriations. The management of scientific research funds has not been paid attention to by the relevant personnel, so the implementation of quality is difficult to be satisfactory.

Imperfect Management System. As far as the actual situation at the present stage is concerned, the management system of scientific research funds of local colleges and universities has not yet been perfected. The existing policies and regulations which can be used to guide the management of scientific research funds in local colleges and universities are mostly macro regulations, and it is impossible to deepen the management of scientific research funds at all. At the same time, the types of scientific research projects in local colleges and universities are diverse, the sources of funds are not fixed, and there is often more complex intersecting phenomenon of crosswise and longitudinal scientific research funds. Even if the universities have established the system related to the management of scientific research funds, it is difficult to give consideration to all types of funds.

Nonstandard Management Behavior. Because of the wide source of funds and many types of scientific research projects, it is difficult to have a clear classification for the management of scientific research funds. Many project funds need to be reported in different channels, and the difficulty of financial management is increased. Due to the fact that many scientific research fund approvers in colleges and universities are not the professional financial managers, they often violate financial systems when dealing with the financial work, and then the level and quality of the management of scientific research funds in local colleges and universities are affected.

Lack of Budget Supervision. The government departments of our country require that the scientific research funds of colleges and universities must go through the budget management and have corresponding detailed budgeting. However, most of the personnel engaged in budgeting within the local colleges and universities are internal personnel of scientific research institutions. This part of the staff has no corresponding financial knowledge, and the budgeting is arbitrary and blindness, which often leads to the deviation of the budget and the impact of the final accounts. So the financial staff have to carry out the large-scale correcting entry in the implementation of financial management, which not only increases the workload of the financial staff, affects the working efficiency of the financial staff, reduces the quality of the financial management, but also may make the final data of the financial management seriously lack the authenticity. At the same time, the management of scientific research funds in colleges and universities needs the corresponding supervision to ensure the scientific development. However, at the present stage, the supervision of scientific research funds in local colleges and universities is generally inadequate, and the inadequate supervision provides the convenient conditions for the randomness of the management of scientific research funds, and it may eventually affect the scientific development of the management of scientific research funds in local colleges and universities.

Improper Expenditure on Scientific Research Funds. In recent years, the sources of scientific research funds in local colleges and universities have been widening, and the total amount of funds has been increasing. However, with the increase of the number of funds, the number of scientific research projects is increasing. The amount of capital growth is always difficult to fit the needs of project funds, which leads to the "insufficient state" of scientific research funds of universities. At the same time, due to the lack of corresponding guidance methods in colleges and universities, and the difference of the policies in different colleges and universities, it is easy to have the problem of the contradiction between the financial staff and the scientific research personnel, or the problem of mutual comparison of scientific researchers, for example, the proportion of service charge and entertainment expense in scientific research funds is difficult to be controlled, the cost of equipment resources is difficult to be counted, fixed assets are purchased repeatedly and funds are left unused and wasted.

\section{Strategies to Promote the Scientific Development of Scientific Research Funds Management in Local Colleges and Universities}

The management of scientific research funds in local colleges and universities should be optimized. The ways and methods of promoting scientific development of scientific research funds 
management in local colleges and universities should be varied, for example, from the perspective of national legislation, we should formulate laws and regulations related to the management of scientific research funds in universities, and increase the management and publicity of research funds within universities. Constrained by space, it is difficult for this paper to discuss all the methods one by one. Only five strategies are put forward, hoping to contribute to the scientific development of scientific research funds management in local colleges and universities.

Correcting the Management Attitude. The relevant education and propaganda work should be actively carried out, and the ideological quality of the management personnel of scientific research funds within the local colleges and universities should be improved to ensure that they have the right management ideas of scientific research funds, and try to deepen the research on the management of scientific research funds in local universities, and design the optimization measures to solve problems. We should also make good efforts to create a good environment for the management of scientific research funds in local colleges and universities and create good conditions for the scientific development of scientific research funds management in local colleges and universities.

Perfecting the Management System. First of all, we should actively build a three-in-one linkage management mechanism, and actively contact financial staff, researchers and scientific and technological institutions to ensure that all kinds of information can be shared in time. Concretely speaking, after the successful application of scientific and technological personnel, the related project information should be transmitted to the scientific research institutions in a timely manner. After undertaking the project, the scientific research institutions should deliver it to the financial department in a timely manner and supervise and urge the financial departments to carry out the related work. In this process, the scientific and technological institutions play a vital role. On the one hand, they need to transfer the project information of scientific researchers to financial staff, and also need to collect all kinds of financial information from the financial department actively, so as to make overall regulation and control of research funds and prevent the problem of fund waste. On the other hand, they need to improve the reward and punishment measures for the use of funds, actively contact the scientific research department, the financial department, the personnel department and the asset department to jointly build the reward and punishment measures for the use of funds, and encourage scientific and technical personnel within the school to use scientific research funds to purchase instruments, to share instruments as much as possible and to eliminate the waste of all kinds of instruments and equipment. Those who have obvious savings behaviors in the use of funds should be encouraged and commended, and those who have significant wasteful behaviors in the use of funds should be punished, and if necessary, the institutions can cancel their scientific research funds support.

Regulating Management Behavior. The scientific research departments should actively contact the financial departments, formulate scientific and reasonable methods for the management of scientific research funds on the basis of taking full consideration of the actual conditions of local colleges and universities, and consciously standardize the use of scientific research funds and control the proportion of service charge and entertainment expense starting from the detail point of view, so as to reduce the expense which is not related to the research projects as far as possible, minimize the blindness of the funds management of financial management staff, and improve the quality of the management of scientific research funds in colleges and universities. At the same time, the management behavior of the personnel in the financial department should be restrained and standardized to ensure that the financial figures submitted by the scientific research department are examined by the financial department, and guarantee that only the financial figures that meet the conditions of reporting can be stamped with the official seal, otherwise it will be regarded as the scientific research cost that is not approved.

Increasing the Intensity of Budget Supervision. The strength of cost accounting work of scientific research funds should be increased. Before the research project is carried out, all the funds needed by the project should be checked when accounting for existing resources, and the waste of funds should be avoided as much as possible. After the completion of the scientific research project, 
the financial institutions should actively urge the researchers and research institutions to timely check all kinds of unfinished research resources, and settle accounts as soon as possible, so as to avoid the loss of funds.

Constructing High Quality Management team. The management of scientific research funds in local colleges and universities is closely related to the internal scientific research personnel and internal financial management personnel in colleges and universities. There is no doubt that the quality of the relevant personnel will directly affect the implementation quality of the management of scientific research funds. Therefore, local colleges and universities should constantly improve the management professionalism of the relevant person, optimize their management team by means of education and training, and lay a solid foundation for the implementation of high-quality scientific research funds management.

\section{Conclusions}

In summary, at present, there are some problems in the management of scientific research funds in local colleges and universities, such as incorrect management attitude, imperfect management system and nonstandard management behavior. The existence of these problems not only restricts the management of scientific research funds in local colleges and universities, but also brings some obstacles to the development of scientific research work in local colleges and universities. The relevant personnel in local colleges and universities need to further study the management of scientific research funds of colleges and universities at present stage, set up corresponding strategies based on the problem, and create favorable conditions for the smooth development of scientific research work in colleges and universities taking the improvement of the scientific management of scientific research funds of local colleges and universities as the way.

\section{References}

[1] G.M.Yang and C.Y.Lu: Discussion on the Problems and Strategies in the Management of Scientific Research Funds in Local Colleges and Universities[J], China Adult Education, 2012(9):13-15.(In Chinese)

[2] Z.H.Zhang, Z.Zhou and H.Q.Wang: Discussion on the Mode Innovation of the Management of Scientific Research Funds in Local Colleges and Universities [J], Journal of Jiangsu Second Normal University, 2012(6):74-76.(In Chinese)

[3] H.L.Wang: Reflection on the Internal Audit of the Management of Scientific Research Funds in Local Colleges and Universities[J], Journal of Anshan Normal University, 2011, 13(5):103-105.(In Chinese)

[4] X.L.Wang and L.Y.Yao: Research on the Current Situation and Reform of Scientific Research Funds Management in Local Colleges and Universities in China[J], Journal of Shandong Agricultural Engineering College, 2016, 33(12):141-142.(In Chinese)

[5] M.Zhang: Study on the Long-Term Mechanism of Strengthening the Management of Scientific Research Funds by Local Colleges and Universities[J], Journal of Education, 2015(3):37-38.(In Chinese)

[6] M.Qu, Y.Q.Li, Y.Song, etc: How to Improve the Level of Scientific Research Management in Local Colleges and Universities[J], Chinese University Technology Transfer, 2013(12):28-29.(In Chinese)

[7] H.J.Zhao: The Design and Implementation of the Scientific Research Management Platform Function of Tianjin Normal University[D], East China Normal University, 2010. (In Chinese)

[8] S.H.Chen: Research on Countermeasures to Strengthen the Management of Scientific Research Funds in Colleges and Universities[J], The Merchandise and Quality, 2014(11):58-58.(In Chinese)

[9] D.S.Li: Thinking on Scientific Management of Scientific Research Funds in Colleges and Universities[J], Finance and Accounting Monthly, 2013(10).(In Chinese)

[10] X.Huang: The Scientific Idea of Establishing the Management System of Scientific Research Funds in Colleges and Universities[J], Modern Business Trade Industry, 2010, 22(22):311-312.(In Chinese) 